\title{
LEGAL REQUIREMENTS ON WASTE WATER DISCHARGE INTO RIVERS, LAKES AND SEA IN POLAND DURING THE PERIOD OF 1945-2005
}

\author{
Piotr KOWALIK \\ Gdańsk University of Technology, Poland
}

\begin{abstract}
Post-war period in the area of water protection is studied not only in Poland, but in many countries of Central and Eastern Europe. The subjects of such analysis are: the legislation of water protection, economy of waste water treatment plants (WWTP) and the progress in the technology of WWTP. The understanding of the approach of the water protection and wastewater dumping became quite important in the last decades for cities, countries and around of the Baltic Sea. After 1945 many different rules of the waste water discharge to rivers, lakes, internal seas and marine water existed. There are many different evaluations, prepared by several professors, like Z. Rudolf, M. Roman, J. Dojlido, M. Gromiec and others. Concepts of these authors were taken into account in this paper. In this publication the evolution of the general rules of water protection during the period of 1945-2005 is presented and the example of the calculation is given, to illustrate the changes in the legal requirements over time.
\end{abstract}

\section{PERIOD BEFORE THE SECOND WORLD WAR}

The evolution of Polish legislation related to the wastewater treatment is presented in many details by Roman and Tabernacki [13]. They wrote that the beginning of the legal requirements related to the wastewater dumped into open water started in Poland in 1922. The legal act called "Water Law" was issued on 19th September 1922 (Dz.U. RP 1923/125/1016). It was modified several times. The full integrated text was published in 1928 but further changes were introduced in 1934, 1947,1950 and 1952. Water Law was binding in Poland until 1962, when new "Water Law" was prepared (30 May 1962, Dz.U. PRL 1962/34/158). In the first Water Law from 1922, as stated by Roman and Tabernacki [13] "it was forbidden to pollute waters. That was an obligation on the registration on the wastewater discharge and a possibility of the state authority to stop the discharge of wastewater into rivers, lakes and sea. Responsibility of the water polluter and introduction of the concept of the sanitary zone to protect the water intakes for water supply systems were also included."

Roman and Tabernacki [13] indicate that the sanitary legislation was issued for the health resorts in 1923 (Decree of Minister of Public Health of 19 November 1923 related to the sanitary standards of public health resorts, Dz.U. RP 1923/125/1016). This decree stated that "it was necessary to establish the sanitary protection zones of the river catchment areas if the public health resorts are supplied in water from these rivers". This decree was binding until 1962, when new water law was issued. 
The next statute law to be considered was the Decree of the President of the State from 16 March 1928 related to the matter of the discharge of pollutants and rain water (Dz.U. RP 1928/32/311). According to Roman and Tabernacki [13] "in this decree the President of Poland imposed an obligation to all communes of the country to take care on the discharge of pollutants and rain water (pollutants mean here the excreta of humans and animals, sewage, solid waste and household refuses) and to oblige the Minister of Internal Affairs, Minister of Public Works and Minister of Social Care and Health to establish the standards related to the treated wastewater, ready to be discharged to the open waters or to the ground". Unfortunately these standards were never issued by these ministers, even if the preliminary proposals were well prepared, according to Rudolf [14, 15].

In the year 1932 the Law on Fishery was issued (7 March 1932, Dz.U. RP 1932/35/357 and $1938 / 87 / 58$ ). This last law stated that it was not allowed to pollute waters in the degree harmful for fishing and that it is necessary to establish the permissible level of pollution of the open waters. This Law on Fishery was obligatory in Poland until 1961, when the new regulations related to the protection of water against pollution entered into force (31 January 1961, Dz.U. PRL 1961/27/33).

\section{POST-WAR PERIOD 1945-1955}

Just after the second world war, in 1945, several regulations were in use. They included the "Water Law" issued in 1922, Decree of President of Poland related to the discharge of pollutants and rain water from 1928, Decree of Minister of Public Health on sanitary rules of the health resorts of 1923 and the Law on Fisheries of 1932. In the first years after the end of the war some statute laws related to the protection of the waters were issued. These laws were described by Goliszewski [2], Roman and Tabernacki [13] and others. They had the form of instructions and dunning letters:

(a) Instruction of the Minister of Industry and Trade nr 4 of 3 February 1947 related to the obligation of industry to create and to maintenance waste water treatment plants Official Journal of Ministry of Industry $\mathrm{Nr} 2$, item 40;

(b) Instruction of the Minister of Industry and Trade of 18 August 1948 related to the obligation of industry to possess and to keep working waste water treatment plants Ministry of Industry and Trade, General Department, OGIIA 0363/178 (see [18]);

(c) Decree of the Minister of Health of 15 September 1948 on the sanitary rules in the maritime harbours and ports (Dz.U. RP 1948/45/335);

(d) Dunning Letter of 16 February 1949 (nr E/I/389/49) related to the water supply and discharge of pollutants - Official Journal of the Ministry of Health, $\mathrm{nr} 6$, item 39;

(e) Dunning Letter of 23 August 1949 (nr E.I. 29/b/659/49) on the protection of open waters against pollution - Official Journal of the Ministry of Health, nr 18, item 141.

The basic law related to the conditions of the discharge of waste water into open waters was issued in 1950 [13]. It was the Decree of the Minister of Communal Economy of 2 September 1950 on the obligatory conditions related to the wastewater discharged into water bodies and to the ground (Dz.U. PRL 1950/41/371). It was issued according to the binding Decree of the President of Poland of 1928. Mentioned authors wrote that "in this decree of Minister of Communal Economy had introduced the classification of the surface waters into four categories, related to the potential utilisation of waters (category I - water of the highest quality, category IV - water of the lowest quality) and for these four categories the demands related to the quality of the treated wastewater discharged to the open waters were established. The main idea consisted of the understanding that treated wastewater may change the quality 
of open waters in different degrees. The parameters established related to the treated wastewater discharged to the open waters took into account the degree of the dilution of wastewater by the open water and the consequences of the self-purification of open waters after discharge of wastewater."

In order to perform an action against harmful wastewater, against pollution of open waters and soils and to utilize the waste water as a resource an Resolution of the Government of 20 August 1955 on the protection of the waters against pollution and to prevent harmful influences of wastewater and to utilize the wastewater as a resource was used (Resolution of Government $\mathrm{Nr}$ 668/55). Goliszewski [2] evaluated this resolution and wrote: "resolution was addressed to the ministers responsible for different factories discharging wastewater and stressed the responsibility for the proper treatment of wastewater in considered sectors of the state economy and the need to control if all factories are following the obligatory legislation on the wastewater treatment and discharge. The resolution of government stated that it is strictly forbidden to construct, modernize or reconstruct any factory without proper solution on the wastewater treatment, and it is forbidden to open any factory if at the same moment the wastewater treatment plant is not opened. Managers of the factories who are responsible for discharge of sewers into rivers should keep the proper maintenance of the wastewater treatment plants. All the permits related to the discharge of wastewater from the factories or cities to the open waters should be re-evaluated to be sure, that the quality of open water is not declining. This resolution of government was related as well to the problems of human resources, materials, research, technical documentation, relation of localization of new factories and cities with protection of the quality of open waters" (p. 247). This resolution was mainly on the paper and was not implemented in many respects.

\section{THE SIXTIES}

The new law on water protection against pollution was issued on 31st January 1961 (Dz.U. PRL 1961/27/33). As a consequence of this law the Decree of the Prime Minister of Poland of 28 February 1962 related to the standards of the permissible pollution of open waters and the conditions of the quality of treated wastewater discharged to waters and ground was issued (Dz.U. PRL 1962/17/75). In this last decree according to Roman and Tabernacki [13] "5 different types of the utilization of open waters were established and the quality classes of these waters were proposed. Conditions related to the treatment of wastewater and standards of treated wastewater were derived from the general rules of the quality of water receiving the wastewater and of the processes of self-purification of water, after mixing of waste water with open water. This Decree established some quality requirements related to the treated wastewater concerned, if the amount of wastewater was large and the quality of water in the river was small, in the case than the rate between flow of wastewater and flow of river water was in the range from 1:6 to 1:20."

\section{THE SEVENTIES AND EIGHTIES}

During the year 1962 the New „Water Law” was prepared (Water Law, 30 May 1962, Dz.U. PRL 1962/34/158). This water Law stated that the government should establish the classes of the quality of open waters and conditions and norms related to the treated wastewater. But much later in 1970 the instruction of the Council of Ministers of Poland, changing the decree from 1962 was issued. The new instruction of 9 June 1970 concerned the permissible levels of pollution of waters and conditions of discharge of wastewater into open water and into the ground (Dz.U. PRL 1970/17/144). 
"In the Polish environmental legislation from year 1970 - in contrary to many other countries - there were no values of the permissible concentrations of pollutants in the treated wastewater" (Koblak-Kalinska, 1992). "Permissible concentrations in the treated wastewater for particular factories or cities were calculated on individual basis and established in the administration decisions for factories or cities in the form of water-legislation permits" (Koblak-Kalinska, 1992, s. 107). Roman and Tabernacki [13] are indicating, that the instruction of 1970 introduced 3 classes of the quality of open water with relation to the potential use of rivers, lakes and sea. According to these authors "for every class of water 49 indicators of the quality were established. It was stated by law that if the treated wastewater is discharged into the river, the class of the quality of this open water cannot be changed drastically. The class of quality of open water should be the same as before discharge of wastewater, after assumption that the mixing of wastewater with open water will be immediate and full. For the calculation of the balance of water and pollutants it was assumed, that river is described by the mean low water flow (Qain $\mathrm{m}^{3} / \mathrm{s}$ ) and the discharge is described by the hourly flow of sewage (or maximal hourly flow of sewage, if this is at least two times bigger that the mean hourly flow), taking this as q in $\mathrm{m}^{3} / \mathrm{s}$."

According to this regulations the load of the pollution discharged into river by the WWTP no $\mathrm{i}\left(\mathrm{L}_{\mathrm{i}}\right)$ is equal to:

$$
\mathrm{L}_{\mathrm{i}}=\mathrm{q}_{\mathrm{i}} \cdot \mathrm{S}_{\mathrm{i}}
$$

Load of the pollution in the river below the WWTP after full mixing of sewage with river water should not be bigger than: $Q_{i} \cdot N_{i}$, where $N_{i}$ is a permissible maximal concentration of $\mathrm{BOD}_{5}$ in $\mathrm{g} / \mathrm{m}^{3}$ during the mean low water flow $\mathrm{Q}_{\mathrm{i}}$. The load of wastewater discharged into river must be limited to the value:

$$
\mathrm{q}_{\mathrm{i}} \cdot \mathrm{s}_{\mathrm{i}} \leq \mathrm{Q}_{\mathrm{i}} \cdot \mathrm{N}_{\mathrm{i}}
$$

where $\mathrm{N}_{\mathrm{i}}$ is the obligatory level of the purity of river water. We have then:

$$
\left(\mathrm{q}_{\mathrm{i}} \cdot \mathrm{s}_{\mathrm{i}}\right) / \mathrm{Qi} \leq \mathrm{N}_{\mathrm{i}}
$$

where $s_{i}$ is permissible concentration of the considered pollutant in wastewater discharged into river, $\mathrm{g} / \mathrm{m}^{3}$ (for example $\mathrm{BOD}_{5}$ ); $\mathrm{N}_{\mathrm{i}}$ - permissible concentration of considered pollutant in river water in the considered class of quality of river, $\mathrm{g} / \mathrm{m}^{3}$ (for example $\mathrm{BOD}_{5}$ ); $\mathrm{q}_{\mathrm{i}}-$ wastewater flow (meaning hourly flow or maximal hourly flow), $\mathrm{m}^{3} / \mathrm{s} ; \mathrm{Q}_{i}-$ mean low river water flow, $\mathrm{m}^{3} / \mathrm{s}$. Permissible concentration of the pollution in the wastewater discharged into the rivera ${ }_{i}$ can be calculated from the formula:

$$
\mathrm{s}_{\mathrm{i}} \leq\left(\mathrm{Q}_{\mathrm{i}} / \mathrm{q}_{\mathrm{i}}\right) \mathrm{N}_{\mathrm{i}}
$$

This method of calculation of the permissible concentrations in the treated wastewater $\mathrm{s}_{\mathrm{i}}$ was elaborated by prof. H. Manczak [3] and was implemented according to the text of mentioned instruction of 1970. Koblak-Kalińska (1992) is indicating that ,instruction was modified several times in 1975, 1982 and 1987, but the changes were not related to the method of calculation of the permissible concentrations in the treated wastewater".

The main idea of the method called "method of Manczak" according to Koblak-Kalinska (1992) can be described as follows: 
- "state environmental administration of Poland was obliged to indicate that the river, lake or sea posses the certain class of purity of water;

- state environmental administration of Poland was obliged to calculate the permissible concentrations of pollutants in the treated wastewater, to be sure that the quality of water of river, lake or sea will stay at the same level as before discharge;

- the quality of open water should be related to the process of self-purification, improving the situation of open water."

According to Koblak-Kalinska (1992) from Polish Ministry of Environmental Protection ,application of his method - theoretically quite coherent and rational, linking the conditions of treated wastewater with the conditions of the quality of open water - was in practice not operational at all. It was not possible to obtain the proper hydrological values about rivers and the proper evaluation of the efficiency of the self-purification. As a result the values of the permissible concentrations of pollutants in the treated wastewater were wrongly established. It was not clear if the quality of water in the river should be actual or desirable." According to this author "method of Manczak, even if the input data were properly gathered and calculations were correct, allowed that the big factories situated close to relatively big rivers with big flow and large capacity discharged to the river large loads of pollution, even if the existing technology was able to reduce these loads easily. On the other hand the presence of small rivers with low flow intensity caused that some factories or cities were obliged to reduce the loads with not realistic solutions with most sophisticated technologies and most costly equipment."

\section{RECENT PERIODa- THE NINETIES}

A new Decree of the Minister of Environmental Protection, Natural Resources and Forestry was issued on 5th November 1991. This decree gives the classification of the quality of open waters and conditions of the quality of the treated wastewater discharged into the water or into the ground (Dz.U. 1991/116/503).

The Appendix 1 of this decree gives the permissible values of 6 main indicators of the pollution ( $\mathrm{BOD}_{5}, \mathrm{COD}$, suspended solids, $\mathrm{N}_{\text {tot }}, \mathrm{N}-\mathrm{NH}_{4}$ and $\mathrm{P}_{\text {tot }}$ ).

Table 1. Maximal permissible values are as follows.

\begin{tabular}{|c|c|c|}
\hline Indicator & Unit & $\begin{array}{c}\text { Permissible } \\
\text { values }\end{array}$ \\
\hline $\mathrm{BOD}_{5}$ & $\mathrm{gO}_{2} / \mathrm{m}^{3}$ & $\leq 30$ \\
\hline COD & $\mathrm{gO}_{2} / \mathrm{m}^{3}$ & $\leq 150$ \\
\hline Susp. solids & $\mathrm{g} / \mathrm{m}^{3}$ & $\leq 50$ \\
\hline $\mathrm{N}_{\mathrm{tot}}$ & $\mathrm{gN} / \mathrm{m}^{3}$ & $\leq 30$ \\
\hline $\mathrm{N}-\mathrm{NH}_{4}$ & $\mathrm{gN} / \mathrm{m}_{3}$ & $\leq 6$ \\
\hline $\mathrm{P}_{\text {tot }}$ & $\mathrm{gP} / \mathrm{m}^{3}$ & $\leq 5(1, \overline{5}$ into sea $)$ \\
\hline
\end{tabular}

All these requirements are related to the wastewater treatment plants without differences according to the size of the plant, starting from the outflow on the level above $5 \mathrm{~m}^{3} /$ day. As indicated by Dojlido [1] "the requirements in the European Union are relating the permissible values to the size of the WWTP but it was not the case with Polish regulation".

The Appendix 2 to the decree of 1991 indicated the maximal permissible concentrations of the 47 parameters of the wastewater quality, divided into 5 subgroups $[8,9]$ : 
$\mathrm{A}$ - basic indicators (6 parameters, including $\mathrm{BOD}_{5}, \mathrm{COD}$ and suspended solids);

$\mathrm{B}$ - eutrophic indicators (4 parameters like $\mathrm{N}-\mathrm{NH}_{4}, \mathrm{~N}-\mathrm{NO}_{3}, \mathrm{~N}_{\text {tot }}$ and $\mathrm{P}_{\text {tot }}$ );

$\mathrm{C}$-non-organic indicators ( 9 parameters, including chlorides, sulphides and dissoluted substances);

$\mathrm{D}$ - hazardous non-organic indicators ( 17 parameters, including ions of 8 heavy metals $-\mathrm{Cr}^{+3}$, $\mathrm{Cr}^{+6}, \mathrm{Zn}, \mathrm{Cd}, \mathrm{Cu}, \mathrm{Ni}, \mathrm{Pb}, \mathrm{Hg}$ and cyanides);

$\mathrm{E}$ - hazardous organic indicators (11 parameters including volatile phenols, insecticides, detergents and petrols).

Those 47 indicators are present in Polish regulations but in the European Union Directives only 5 indicators exists, where $\mathrm{BOD}_{5}, \mathrm{COD}$ and suspended solids are obligatory for all wastewater treatment plants and the indicators like $\mathrm{Nat}_{\mathrm{t}}$ and $\mathrm{P}_{\mathrm{tot}}$ are necessary if the WWTP is discharging wastewater into open water sensitive for eutrophication. On the other hand in Polish regulations from 1991, in contrary to European Union Directives the sewage sludge and the concept of the areas sensitive for eutrophication processes are not mentioned. But anyway the Polish legislation after 1991 on the treated wastewater discharged to the open waters were very restrictive and much more demanding than the European Union Directives [1].

\section{LEGISLATION AFTER YEAR 2002}

Recently we are observing the changes of the legal status of water protection. Decree of the Minister of Environment of 29 November 2002 was issued on the conditions needed during the discharge of wastewater into open water or to the ground and substances hazardous for water environment (Dz. U. 2002/212/1799). Next Decree was issued in 2004 (Dz.U. 2004/168/1763). The demands related to the quality of the treated wastewater were greatly changed and liberalized. They are as follows:

Table 2. Maximal permissible indicators of the pollution in the treated wastewater were established for small communal WWTP.

\begin{tabular}{|c|c|c|c|c|}
\hline \multirow[t]{2}{*}{ No. } & \multirow[t]{2}{*}{$\begin{array}{l}\text { Name of } \\
\text { indicator }\end{array}$} & \multirow[t]{2}{*}{ Unit } & \multicolumn{2}{|c|}{$\begin{array}{l}\text { Maximal permissible value of the } \\
\text { indicator } \\
\text { for the number of the equivalent } \\
\text { persons: }\end{array}$} \\
\hline & & & belowa2000 & $\begin{array}{c}\text { from } 2000 \text { to } \\
9999\end{array}$ \\
\hline \multirow{2}{*}{1} & \multirow{2}{*}{$\mathrm{BOD}_{5}$} & $\mathrm{mg} \mathrm{O}_{2} / \mathrm{L}$ & 40 & 25 \\
\hline & & $\min . \%$ of red. & - & $70-90$ \\
\hline \multirow{2}{*}{2} & \multirow{2}{*}{ COD } & $\mathrm{mg} \mathrm{O}_{2} / \mathrm{L}$ & 150 & 125 \\
\hline & & $\min . \%$ of red. & - & 75 \\
\hline \multirow{2}{*}{3} & \multirow{2}{*}{ Suspended solids } & $\mathrm{mg} / \mathrm{L}$ & 50 & 35 \\
\hline & & $\min \%$ of red. & - & 90 \\
\hline \multirow[t]{2}{*}{4} & \multirow[t]{2}{*}{ Total nitrogen } & \multirow[t]{2}{*}{$\begin{array}{c}\mathrm{mgaN} / \mathrm{L} \\
\mathrm{min} \% \text { of red. }\end{array}$} & $\begin{array}{c}30 \text { (only for } \\
\text { lakes) }\end{array}$ & $\begin{array}{c}\text { 15a(onlyafor } \\
\text { lakes) }\end{array}$ \\
\hline & & & - & - \\
\hline \multirow{2}{*}{5} & \multirow{2}{*}{ Total phosphorus } & $\mathrm{mg} \mathrm{P} / \mathrm{L}$ & 5 (only for lakes) & 2 (only for lakes) \\
\hline & & $\min . \%$ of red. & - & - \\
\hline
\end{tabular}


In contrary to the demands from the decree of 1991 the new regulations from 2002 are much milder and quite similar to the legal obligations in the European Union.

\section{EXAMPLES OF THE CALCULATIONS OF THE WASTEWATER QUALITY}

Example of the calculations were presented by Sedzikowski and Bonikowski [17], taking into account the legal status from the year 1970. Some comparisons to the state of the year 1991 and 2002 are given here as well. Input data are as follows:

Table 3. Description of the untreated wastewater

\begin{tabular}{ccc} 
No. of & $\begin{array}{c}\text { Flow of } \\
\text { wastewater } \mathrm{q}_{\mathrm{i}} \\
\mathrm{m}^{3} / \mathrm{s}\end{array}$ & $\begin{array}{c}\text { Concentration of } \\
\mathrm{BOD}_{5} \text { in untreated } \\
\text { wastewater } \mathrm{S}_{\mathrm{i}} \\
\mathrm{kg} / \mathrm{m}^{3}\end{array}$ \\
\hline 1 & 0,04 & 0,5 \\
2 & 0,02 & 0,6 \\
3 & 0,12 & 5,0 \\
4 & 0,02 & 0,5 \\
\hline
\end{tabular}

One may note that in the point no. 3 we have the biggest outflow of the wastewater $\left(\mathrm{q}_{3}=0,12\right.$ $\left.\mathrm{m}^{3} / \mathrm{s}\right)$ and the highest concentration of pollution in the untreated wastewater $\left(\mathrm{S}_{3}=5,0 \mathrm{~kg} / \mathrm{m}^{3}\right)$. After introduction of the symbols: $s_{i}$ - concentration of pollution in the wastewater after treatment, $\mathrm{kg} / \mathrm{m}^{3}, \mathrm{~S}_{\mathrm{i}}$ - concentration but before treatment, $\mathrm{kg} / \mathrm{m}^{3}, \eta_{\mathrm{i}}$ - reduction of load in the WWTP called as well the efficiency of WWTP and:

$$
\eta_{\mathrm{i}}=\left(\mathrm{L}_{\text {in }}-\mathrm{L}_{\text {out }}\right) / \mathrm{L}_{\text {out }}
$$

where L - means the load of the pollution, and index "in" is related to the load which is inflowing to WWTP:

$$
\mathrm{L}_{\mathrm{in}}=\mathrm{q}_{\mathrm{i}} \cdot \mathrm{S}_{\mathrm{i}}
$$

And the index "out" is related to the load witch is outflowing WWTP:

$$
\mathrm{L}_{\text {out }}=\mathrm{q}_{\mathrm{i}} \cdot \mathrm{s}_{\mathrm{i}}
$$

Efficiency of the WWTP is $\eta_{i}$ and it is describing the degree of the elimination (reduction ) of the load of pollution:

$$
\eta_{\mathrm{i}}=\left(\mathrm{S}_{\mathrm{i}}-\mathrm{s}_{\mathrm{i}}\right) / \mathrm{S}_{\mathrm{i}} ; \quad 0 \leq \eta_{\mathrm{i}} \leq 1
$$

where $s_{1}$ and $\eta_{i}$ are the decisions to be calculated. Load of pollution in the river below the WWTP after full mixing of wastewater with river water should be lower than the value: $Q_{i}$. $N_{1}$, where $N_{i}$ - is the permissible concentration of BOD $_{5}\left(\mathrm{~kg} / \mathrm{m}^{3}\right)$ for the mean low flow of water in the river $\left(\mathrm{Q}_{\mathrm{i}}\right)$. It means that the load discharged from the WWTP is limited by the formula:

$$
\mathrm{q}_{\mathrm{i}} \cdot \mathrm{s}_{\mathrm{i}} \leq \mathrm{Q}_{\mathrm{i}} \cdot \mathrm{N}_{\mathrm{i}}
$$


where $\mathrm{N}_{\mathrm{i}}$ is here the obligatory status of the water purity of the river. We can derive:

$$
\left(q_{i} \cdot s_{i}\right) / Q i \leq N_{i}
$$

and from the definition of the WWTP efficiency we have:

and

$$
\eta_{\mathrm{i}} \cdot \mathrm{S}_{\mathrm{i}}=\mathrm{S}_{\mathrm{i}}-\mathrm{s}_{\mathrm{i}}
$$

or

$$
\mathrm{s}_{1}=\mathrm{S}_{\mathrm{i}} \cdot\left(1 \mathrm{a}-\eta_{\mathrm{i}}\right)
$$

$$
\left(\mathrm{q}_{\mathrm{i}} / \mathrm{Q}_{\mathrm{i}}\right) \cdot \mathrm{S}_{\mathrm{i}} \cdot\left(1-\eta_{\mathrm{i}}\right) \leq \mathrm{N}_{\mathrm{i}}
$$

This is the limiting condition in the considered decision model. Due to the introduced limitation it was possible to calculate the permissible level of the WWTP efficiency $\eta_{\text {ip }}$. From the last formula one can derive:

$$
1-\eta_{\text {ip }}\left(N_{i} Q_{i}\right) /\left(q_{i} S_{i}\right)
$$

and the permissible efficiency of WWTP is equal to:

$$
\eta_{i p} \geq 1-\left(N_{i} Q_{i}\right) /\left(q_{i} S_{i}\right)
$$

It means that if we can introduce here the input data of $N_{i}, Q_{i}, q_{i}$ and $S_{i}$ it is possible to calculate the values of $\eta_{\text {ip. }}$. It is given in the example of calculation below:

Table 4. Input data and permissible efficiency.

\begin{tabular}{cccccc}
\hline No. & $\mathrm{N}_{\mathrm{i}}$ & $\mathrm{q}_{\mathrm{i}}$ & $\mathrm{Q}_{\mathrm{i}}$ & $\mathrm{S}_{\mathrm{i}}$ & $\eta_{\text {ip }}$ \\
\hline 1 & 0,008 & 0,04 & 2,0 & 0,5 & $\geq 0,20$ \\
2 & 0,004 & 0,02 & 3,5 & 0,6 & $\geq 0,01$ \\
3 & 0,004 & 0,12 & 3,9 & 5,0 & $\geq 0,982$ \\
4 & 0,004 & 0,02 & 0,2 & 0,5 & $\geq 0,92$ \\
\hline
\end{tabular}

It was calculated according to the legal requirements of year 1970. If we take the legal status from year 1991, the treated wastewater should be as follows:

and permissible efficiency of WWTP should be:

$$
\mathrm{s}_{\mathrm{i}} \leq 0,030 \mathrm{~kg} / \mathrm{m}^{3}
$$

$$
\eta_{i p} \geq\left(S_{i}-0,030\right) / S_{i}
$$

and taking into consideration the input data from above we have for the status of year 1991:

Table 5. Permissible efficiency.

\begin{tabular}{cc}
\hline No. & $\eta_{\text {ip }}$ \\
\hline 1 & $\geq 0,94$ \\
2 & $\geq 0,95$ \\
3 & $\geq 0,994$ \\
4 & $\geq 0,94$ \\
\hline
\end{tabular}


and it is much more demanding and difficult from the point of view of the WWPTP technology than the values derived according to the legislation from 1970. We can note that the requirements from 1970, 1991 and 2002 are very different which is influencing the decisions on investment and technology of WWTP.

Taking again the situation from 1970 described by Sedzikowski and Bonikowski (1971) it was possible to establish that the most economical solution would be as follows:

Table 5. Results for economy solution.

\begin{tabular}{ccllr}
\hline No. & $\begin{array}{c}\mathrm{q}_{\mathrm{i}} \\
\mathrm{m}^{3} / \mathrm{s}\end{array}$ & $\mathrm{q}_{\mathrm{i}} / \mathrm{Q}_{\mathrm{i}}$ & \multicolumn{1}{c}{$\eta_{\text {ip }}$} & $\begin{array}{c}\mathrm{s}_{\mathrm{i}} \\
\mathrm{g} / \mathrm{m}^{3}\end{array}$ \\
\hline 1 & 0,02 & $1: 50$ & 0,70 & 150 \\
2 & 0,04 & $1: 195$ & 0,79 & 126 \\
3 & 0,12 & $1: 38$ & 0,982 & 90 \\
4 & 0,02 & $1: 10$ & 0,95 & 25 \\
\hline
\end{tabular}

But it is important to note that according to the actual regulations from year 2002 for the WWTP smaller than for 2000 inhabitants the treated wastewater should have the concentration $s_{i} \leq 40 \mathrm{~g} / \mathrm{m}^{3}$ and the minimal or permissible efficiency of WWTP is not prescribed at all but if we consider the WWTP serving the population from 2000 to 9999 inhabitants we have $s_{1} \leq 25$, and the minimal reduction of the pollution called as well the efficiency of WWTP will be from 70 to $90 \%$, what means $\eta_{\text {ip }} \leq$ from 0,70 to 0,90 .

The last results of the calculations are indicating that the WWTP no. 4 will have the values of $\mathrm{s}_{\mathrm{i}}$ below $25 \mathrm{~g} / \mathrm{m}^{3}$, but in other locations we have higher degrees of the dilution of wastewater in the river $(\mathrm{q} / \mathrm{Q}=1: 50,1: 195 \mathrm{i} 1: 38)$ and the river is relatively big. Only in the WWTP no. 4 river is relatively small $\left(\mathrm{Q}=0,5 \mathrm{~m}^{3} / \mathrm{s}\right)$, but the demands of the purity class of the river are high $\left(\mathrm{N}_{4} \leq 0,004 \mathrm{~kg} / \mathrm{m}^{3}\right)$. It is visible that if we travel down in the river bed, the water became more and more polluted and in the lower part of the river the efficiency of the WWTP should be higher and higher. It means that if we would apply the regulations from the year 1970 for longer period, the best location of the discharge of the wastewater should be the upper part of the river where the water has the highest purity class and the most costly solutions and highest investment would be demanded close to the most polluted rivers. It is the reason that the requirements from year 1970 were refused in year 1991 and modified in year 2002.

\section{SUMMARY}

The legal requirements related to the quality of the treated wastewater discharged to open waters and to the ground were changed many times in the post-war period. Taking the regulations established in the year 2002 and 2004 we may note the big similarity to the regulations of European Union. Only 5 indicators of the pollution are introduced into the regulation, but only $\mathrm{BOD}_{5}, \mathrm{COD}$ and suspended solids are demanded for all WWTP, and $\mathrm{N}_{\text {tot }}$ and $\mathrm{P}_{\mathrm{tot}}$ are subject to normalization only if the treated wastewater is discharged into lakes or other sensitive open waters. In Poland the state of the quality of the rivers is dramatic and most of them are out of any purity class [5]. It is a reason that the monitoring of the water quality of the rivers is not intensive and most of the efforts are related to observe the efficiency of the WWTPs [3].

We have a problem with the legal requirements for the smallest WWTPs. According to the regulation from year 1991 it was not decided what to do with the discharge below $5 \mathrm{~m}^{3} /$ day 
what means the discharge from below 25 inhabitants. The recent regulations are not giving any indications for the situation with discharge below 2000 inhabitants. Decisions in this matter are taken by the local environmental authorities [7].

We can note that the legal requirements in Poland related to the wastewater discharge were changing during the period 1945-2005. It is important to note that the wastewater from industry and from cities are the main pollution in our rivers, lakes and sea. We have great demands for the investment in new WWTPs or modernization of old WWTPs.

\section{REFERENCES}

[1] Dojlido, J. (Red.), 2000. Warunki odprowadzania ścieków. Monografia KGW PAN Nr. 16, Oficyna Wydawnicza Politechniki Warszawskiej, Warszawa, ss. 64 (all ref erences in Polish).

[2] Goliszewski J., 1958. Ochrona wód powierzchniowych przed zanieczyszczeniem. Wydawnictwo Arkady, Warszawa, ss. 260.

[3] Gromiec M.J., 2000. Podstawy prawne ogólnych warunków oczyszczania ścieków w Unii Europejskiej i w Polsce. W: J. Dojlido (Red.) Warunki odprowadzania ścieków. Monografie KGW PAN Nr. 16, Oficyna Wydawnicza Politechniki Warszawskiej, Warszawa, ss. 7-19.

[4] Kowalik P., 1988. Optymalizacja systemów inżynierii sanitarnej. Wydawnictwo Politechniki Gdańskiej, ss. 129.

[5] Mąkinia J., Dunnette D., Kowalik P., 1996. Water pollution in Poland. European Water Pollution Control, 6(2):26-33.

[6] Mańczak H., 1973. Teoretyczne podstawy ochrony wód przed zanieczyszczeniem. PWN, Wrocław.

[7] Osmulska-Mróz B., 2000. Warunki odprowadzania ścieków komunalnych do wód w świetle wymogów Unii Europejskiej i niektórych państw europejskich. W: J. Dojlido (Red.) Warunki odprowadzania ścieków. Monografie KGW PAN Nr 16, Oficyna Wydawnicza Politechniki Warszawskiej, Warszawa, ss. 21-32.

[8] Przewłocki J., 1995. Ocena krajowych standardów jakości ścieków odprowadzanych do wód i propozycje ich nowelizacji. Materiały Konferencji Naukowo-Technicznej „Problemy oczyszczania ścieków w Dorzeczu Odry”, Wrocław, ss. 103-107.

[9] Przewłocki J., 2000. Analiza porównawcza krajowych standardów jakości ścieków odprowadzanych do wód oraz standardów obowiązujących w Unii Europejskiej. W: J. Dojlido (Red.) Warunki odprowadzania ścieków. Monografie KGW PAN Nr 16, Oficyna Wydawnicza Politechniki Warszawskiej, Warszawa, ss. 33-40.

[10] Roman M., 1988. Ewolucja zasad klasyfikacji wód powierzchniowych i warunków odprowadzania ścieków w Polsce w okresie lat 1918-1988. Materiały Konferencji Naukowo-Technicznej p.t. Postęp techniczny w dziedzinie oczyszczania ścieków, PZITS Katowice.

[11] Roman M., 1989. Ewolucja zasad klasyfikacji wód powierzchniowych i warunków odprowadzania ścieków w Polsce w okresie lat 1918-1988. Materiały Sympozjum p.t. Metody badań i oceny jakości wód powierzchniowych, Polski Komitet Międzynarodowego Stowarzyszenia Badań Zanieczyszczeń i Ochrony Wód (IAWPRC), Warszawa.

[12] Roman M., 1998. Standardy jakości i ochrony śródlądowych wód powierzchniowych w przepisach Unii Europejskiej i w przepisach polskich. Monografia. Seria: Wodociągi i Kanalizacja, PZITS, Warszawa, nr. 1.

[13] Roman M., Tabernacki J., 1992. Kierunki doskonalenia polskich przepisów dotyczących ochrony wód przed zanieczyszczeniem. Gaz Woda i Technika Sanitarna, 5:127-130. 
[14] Rudolf Z., 1929. Normy oczyszczania ścieków. Gaz Woda i Technika Sanitarna, $12: 245-248$.

[15] Rudolf Z., 1930. Normy oczyszczania ścieków według pierwszego polskiego projektu. Gaz Woda i Technika Sanitarna, 1:11-13.

[16] Rudolf Z., 1956. Organizacja i kontrola ochrony wód powierzchniowych przed zanieczyszczeniem w Polsce. Gospodarka Wodna nr 5.

[17] Sędziowski T., Bonikowski A., 1971. Model optymalizacji stopnia oczyszczania ścieków, wpływ skuteczności działania oczyszczalni zlokalizowanych w rozpatrywanej zlewni. Materiały Badawcze IGW, Seria Gospodarowanie Zasobami Wodnymi, 3:3-14.

[18] Śwital S., 1952. Zbiór przepisów o zaopatrywaniu ludności w wodę i usuwaniu nieczystości. PZWL, Warszawa. 